\title{
Preliminary checklist of moths (Lepidoptera: Glossata) of Annamalai Nagar, Tamil Nadu
}

\section{Kathirvelu*}

Department of Entomology, Faculty of Agriculture, Annamalai University, Annamalinagar608002 (Tamil Nadu), India

\section{R. Ayyasamy}

Department of Entomology, Faculty of Agriculture, Annamalai University, Annamalinagar608002 (Tamil Nadu), India

\section{Karthikeyan}

Department of Entomology, Faculty of Agriculture, Annamalai University, Annamalinagar608002 (Tamil Nadu), India

\section{*Corresponding author. E-mail: ckarthirveluau@gmail.com}

\begin{abstract}
The present research was carried out to document the moth fauna of Annamalai Nagar during December, 2015 to November, 2016 comprising four seasons for a period of one year, from agriculture and horticulture ecosystems using light traps and host rearing methods. The sheet method was used to record moth insects individually without any damage. Any moths that alight on the screen were recorded in jars just after sunset between $18.00-23.00 \mathrm{hr}$. A total of 2,679 moths were recorded using all the three types of methods employed in the study. Out of which, light trap was found with maximum of 2,253 moths followed by manual collection (369) and host rearing (57) from four different sites of observation. Among the sites, light trapping of moths were observed maximum (656) in Orchard followed by Experimental farm with 629 numbers. The diversity of moths was observed in the study area of Annamalai Nagar indicated the presence of 70 genera and 56 species identified under nine superfamilies of Clades viz., Obtectomera (Pyraloidea and Thyridoidea) Macroheterocera (Noctuoidea, Bombycoidea, Geometroidea, Lasiocampoidea) Apoditrysia (Pterophoroidea and Cossoidea) Ditrysia (Tineoidea). The families namely Crambidae, Erebidae, Noctuidae, Sphingidae, Bombycidae, Uraniidae, Thyrididae, Eupterotidae, Geometridae, Pterophoridae, Lasiocampidae, Cossidae and Psychidae were observed in the study area. Out of which, the family Erebidae alone had 28 genera and 25 species and found to be the superior family. From the results, it was clear that light trapping was superior in collection of moths during night times.
\end{abstract}

Keywords: Checklist, Diversity, Fauna, Light trap, Moths

\section{INTRODUCTION}

More than half of the world's known animal species are insects (Wilson, 1992) in which Lepidoptera is the second largest and the most diverse order of the class Insecta (Benton, 1995). The present total number of Lepidopteran named species approaches nearly 1,74,250, with butterflies and skippers estimated to comprise around 17,950 , and moths making up the rest (Mallet, 2007). In India, estimated moth species were 11,300 according to Peter Smetacek (2011). Earlier, the order Lepidoptera was divided in to two suborders viz., Rhaphalocera and Heterocera. The moths, which have important role in forest ecosystems as herbivores and as food for various predatory and parasitic organisms. Moths are commonly nocturnal, holometabolous and phy-

\section{Article Info}

DOI:10.31018/jans.v11i2.2063 Received: April 15, 2019

Revised: May 20, 2019

Accepted: May 27, 2019

\section{How to Cite}

Kathirvelu, C. et al. (2019). Preliminary checklist of moths (Lepidoptera: Glossata) of Annamalai Nagar, Tamil Nadu. Journal of Applied and Natural Science, 11(2): 404 - 409 https://doi.org/10.31018/ jans.v11i2.2063 
food chain. These insects are often considered as bio - indicators in biological studies because they are sensitive to habitat change, whose function, population, or status can reveal the qualitative status of the environment. Being primary herbivorous insects, they help in natural control of weeds in an agro-ecosystem. The larvae of moths are active devourer of the tender parts of host plants hence, they are often recognized as pests of variety of crops, vegetables and forest plantations. Therefore, they are treated as economically important insects (Shah and Mitra, 2015). Many investigators have used Lepidoptera as model to assess the impact of disturbance and management practices on various ecosystems (Brehm, 2005).

The current knowledge on the insect fauna of moths is largely based on earlier studies by pioneer workers like Hampson (1892). A series of revisionary studies have been subsequently carried out from different geographical regions. The moths available in Mumbai, Pune and other localities in western India have been largely worked by Cotes and Col.C. Swinhoe followed by Gardner who reported immature stages of Indian Lepidopterans especially Noctuidae, Hypsidae etc. Research on moths of different regions was mostly carried out before 1950 (De Niceville and Marshall (1990), Bingham (1905, 1907), Bell (1919), Bell and Scot (1937), Mani (1986) and Talbot (2013). Extensive faunistic surveys, along with proper identification and documentation, at least to species level, provide the most reliable data for conservation and management of different habitats. No such survey has so far been done in coastal areas of Tamil Nadu related to diversity and population abundance of moths. Hence, understanding the functional role of the indicator groups like moth insects of this region will have a great relevance in assessing the status of ecosystems in the environment. Therefore, a study was undertaken to account the moth fauna and to prepare a checklist of moths of Annamalai Nagar, Tamil Nadu.

\section{MATERIALS AND METHODS}

The present research was carried out in the Department of Entomology, Faculty of Agriculture, Annamalai University, Annamalai Nagar. The study area, Annamalai Nagar is located at $11.39^{\circ} \mathrm{N} 79.71^{\circ} \mathrm{E}$ and $4.680 \mathrm{mts}$. MSL in Cuddalore district of Tamil Nadu state. It has a tropical climate and an average temperature ranges between $25^{\circ} \mathrm{C}$ to $35^{\circ} \mathrm{C}$ during summer (March to May). Winters are very cool with maximum temperature of about $30^{\circ} \mathrm{C}$ and a minimum of about $22^{\circ} \mathrm{C}$. The moth insects were recorded from the experimental farm, garden land, orchard and new area of Annamalai Nagar during December, 2015 to November, 2016 comprising four seasons and for a period of one year. For manual collection, the moths were also rec- orded from light source during night times in possible residential places of Annamalai Nagar.

The sheet method was used to record moth insects individually without any damage. A white cloth sheet $\left(10^{\prime} \times 6\right.$ ') was hung between two vertical poles in such a way that it was just above (half foot) the surface and extended forward over the ground slightly away from direct source of light placed at such a point that the whole sheet from edge to edge brightly reflected the light. A 100 watt Tungsten lamp was used as a light source (Chandra and Sambath, 2013). Any moths that alight on the screen were recorded in jars just after sunset between $18.00-23.00 \mathrm{hr}$. The light trap was operated twice a week in the locality and the moths alight on the screen were recorded. Single specimens from each species were collected and identified in the laboratory. The location of the light trap was changed from time to time within the ecosystem. Only one light trap was used to document the moth's diversity in each ecosystem. In host rearing method, the larvae of moths collected from the field and orchards were reared with their respective food material. The dried leaves were replaced with fresh ones frequently and waste bits and pieces were removed. For soil pupating caterpillars, soil was put into the rearing polythene cover. After adult emergence, they were collected and preserved for identification.

The adults were caught in the insect cover with a piece of cotton dipped in ethyl acetate or chloroform or the captured specimens were introduced into killing bottle. The specimens were pinned using entomological pins (Size 000/001/002/003) obtained from Rescholar Equipments, Haryana. Setting boards were used to spread the wings of specimen in the correct position, until the body is thoroughly dry. A permanent data label $(20 \times 10 \mathrm{~mm}$ or $15 \times 10 \mathrm{~mm}$ ) showing the precise locality, the date of capture and the collector's name was attached to every specimen. The data was printed neatly on archival white card. After pinning, spreading, drying and labeling; the specimens were placed permanently in the store boxes and kept in entomological cabinets at Lepidoptera Research Laboratory, Department of Entomology, Annamalai University. The collected moth specimens were diagnosed after clearing the wings using the procedure given by Triplehorn (1989), following the key characters of Hampson (1892, 1893, 1894, 1895, 1896) and Holloway (1989), their current nomenclature based on LEPINDEX (Beccaloni et al., 2003). The hierarchy of different families of moths was based on the classification by Nieukerken Van et al. (2011).

\section{RESULTS AND DISCUSSION}

The results revealed that a total of 2,679 moths were recorded from the study area in both agriculture and horticulture ecosystems during December 2015 to November 2016. The moths were 
Kathirvelu, C. et al. / J. Appl. \& Nat. Sci. 11(2): 404 - 409 (2019)

Table 1. Moths recorded in Annamalai Nagar during December 2015 to November 2016 by using various methods.

\begin{tabular}{lll}
\hline S.N. & Methods & Total Numbers \\
\hline 1 & Light trap & 2,253 \\
2 & Host rearing & 57 \\
3 & Manual collection & 369 \\
& Total & $\mathbf{2 , 6 7 9}$ \\
\hline
\end{tabular}

Table 2. Moths recorded at different sites in Annamalai Nagar using light trap during December 2015 to November 2016.

\begin{tabular}{lll}
\hline S.N. & Sites of observation & Total numbers \\
\hline 1 & Experimental Farm & 629 \\
2 & Garden land & 541 \\
3 & Orchard & 656 \\
4 & New area & 427 \\
& Total & $\mathbf{2 , 2 5 3}$ \\
\hline
\end{tabular}

Table 3. Preliminary check list of moth fauna of Annamalai Nagar during December 2015 to November 2016.

\begin{tabular}{|c|c|c|c|c|}
\hline S.N. & Family & Sub family & Common name & Scientific name \\
\hline I & Crambidae & & & \\
\hline 1 & & Acentropinae & Rice case worm & Parapoynx stagnalis (Zeller) \\
\hline 2 & & Pyraustinae & Snout moth & Isocentris $\mathrm{sp}$. \\
\hline 3 & & Schoenobiinae & Rice stem borer & Scirpophaga incertulas (Walker) \\
\hline 4 & & Spilomelinae & Swan plant moth & Boccchoris onychinalis (Guenee) \\
\hline 5 & & & Rice leaf folder & Cnaphalocrocis medinalis (Guenee) \\
\hline 6 & & & Cucumber moth & Diaphania indica (Saunders) \\
\hline 7 & & & Shoot and fruit borer & Leucinodes orbonalis (Guenee) \\
\hline 8 & & & Bean pod borer & Maruca vitrata (Fabricius) \\
\hline 9 & & & Bean leaf roller & Omiodes sp. \\
\hline 10 & & & Sweet potato vine borer & Omphisa sp. \\
\hline 11 & & & Green moth & Parotis sp. \\
\hline 12 & & & Green moth & Parotis sp. \\
\hline 13 & & & Banded pearl & Sameodes cancellalis (Zeller) \\
\hline 14 & & & Beet webworm moth & Spoladea recurvalis (Fabricius) \\
\hline II & Erebidae & & & \\
\hline 15 & & Aganainae & Tropical tiger moth & Asota caricae (Fabricius) \\
\hline 16 & & Anobinae & & Plecoptera sp. \\
\hline 17 & & Arctiinae & Fly like moth & Amata sp. \\
\hline 18 & & & Tiger moth & Amerila astrea (Drury) \\
\hline 19 & & & Yellow peach moth & Argina astrea (Drury) \\
\hline 20 & & & Hairy caterpillar & Creatonotes gangis (Linnaeus) \\
\hline 21 & & & Lichen moths & Lyclene sp. \\
\hline 22 & & & Hairy caterpillar & Olepa ricini (Fabricius) \\
\hline 23 & & & & Rajendra vittata (Moore) \\
\hline 24 & & & Salt and pepper moth & Utetheisa lotrix (Cramer) \\
\hline 25 & & Calpinae & Fruit sucking moth & Eudocima homaena (Hubner) \\
\hline 26 & & & Fruit sucking moth & Eudocima materna (Linnaeus) \\
\hline 27 & & & Fruit sucking moth & Eudocima phalonia (Linnaeus) \\
\hline 28 & & & Fruit piercing moth & Thyas coronata (Hubner) \\
\hline 29 & & Catocalinae & Cotton semi looper & Anomis flava (Fabricius) \\
\hline 30 & & & Owl moth & Anticarsia irrorata (Fabricius) \\
\hline 31 & & Erebinae & Fruit piercing moth & Achaea serva (Fabricius) \\
\hline 32 & & & Jig saw moth & Bastilla torrida (Guenee) \\
\hline 33 & & & Triangular striped moth & Chalciope mygdon (Cramer) \\
\hline 34 & & & Black triangle moth & Grammodes geometrica (Fabricius) \\
\hline 35 & & & & Hypena sp. \\
\hline 36 & & & Noctuid moth & Hypopyra verspertilio (Fabricius) \\
\hline 37 & & & Sugarcane looper & Mocis frugalis (Fabricius) \\
\hline 38 & & & $\begin{array}{l}\text { Brown striped semi- } \\
\text { looper }\end{array}$ & Mocis undata (Fabricius) \\
\hline 39 & & & Indian owlet moth & Spirama retorta (Clerck) \\
\hline 40 & & Lymantriinae & Tussock caterpillar & Artaxa guttata (Walker) \\
\hline 41 & & & Tussock moth & Calliteara grotei (Moore) \\
\hline 42 & & & Yellow tail & Euproctis sp. \\
\hline 43 & & & Tussock moth & Euprotis sp. \\
\hline 44 & & & Brown tussock moth & Olene mendosa (Hubner) \\
\hline 45 & & & Clearing tussock moth & Perina nuda (Fabricius) \\
\hline 46 & & & & Somena sp. \\
\hline
\end{tabular}


Kathirvelu, C. et al. / J. Appl. \& Nat. Sci. 11(2): 404 - 409 (2019)

\begin{tabular}{|c|c|c|c|c|}
\hline III & Noctuidae & & & \\
\hline 47 & & Acontiinae & & Acontia crocata (Guenee) \\
\hline 48 & & Eariadinae & Shoot and fruit borer & Earias vittella (Fabricius) \\
\hline 49 & & Heliothinae & American bollworm & Helicoverpa armigera (Hubner) \\
\hline 50 & & Noctuinae & Army worm & Mythimna loreyi (Duponchel) \\
\hline 51 & & & Tobacco caterpillar & Spodoptera litura (Walker) \\
\hline 52 & & & Swarming caterpillar & Spodpotera mauritia (Boisduval) \\
\hline IV & Sphingidae & & & \\
\hline 53 & & Macroglossinae & $\begin{array}{l}\text { Common bumble } \\
\text { hawk moth }\end{array}$ & Cephonodes hylas (Linnaeus) \\
\hline 54 & & & Oleandar hawk moth & Daphnis nerii (Linnaeus) \\
\hline 55 & & & Impatiens hawk moth & Hippotion sp. \\
\hline 56 & & & Tersa sphinx moth & Hippotion sp. \\
\hline 57 & & & Humming bird hawk moth & Macroglossum sp. \\
\hline 58 & & Smerinthinae & Velvet hawk moth & Clanis sp. \\
\hline 59 & & Sphinginae & $\begin{array}{l}\text { Greater death' } s \text { head } \\
\text { hawk moth }\end{array}$ & Acherontia lachesis (Fabricius) \\
\hline 60 & & & $\begin{array}{l}\text { Lesser death' s head } \\
\text { hawk moth }\end{array}$ & Acherontia styx (West wood) \\
\hline 61 & & & Convolvulus hawk moth & Agrius convolvuli (Linnaeus) \\
\hline $\mathbf{V}$ & Bombycidae & & & \\
\hline $\begin{array}{l}62 \\
63\end{array}$ & & Bombycinae & Silk moth & $\begin{array}{l}\text { Bombyx mori (Linnaeus) } \\
\text { Trilocha sp. }\end{array}$ \\
\hline VI & Uraniidae & & & \\
\hline 64 & & Microniinae & Spotted swallow tail moth & Micronia aculeta (Guenee) \\
\hline VII & Thyrididae & & & \\
\hline 65 & & Striglininae & Sapodilla borer & Banisia myrsusalis (Walker) \\
\hline VIII & Geometridae & & & \\
\hline 66 & & Ennominae & Geometrid moth & Chiasmia eleonora (Hubner) \\
\hline 67 & & & Tussock moth & Eucyclodes sp. \\
\hline 68 & & & Black looper & Hyposidra talaca (Walker) \\
\hline 69 & & & Pale oak beauty & Hypomecis punctinalis (Scopoli) \\
\hline 70 & & Geometrinae & Plae green moth & Nemoria sp. \\
\hline 71 & & Sterrhinae & Riband wave & Idaea aversata (Linnaeus) \\
\hline 72 & & & Flower webber & Eublemma sp. \\
\hline 73 & & & Cream wave moth & Scopula floslactata (Haworth) \\
\hline IX & Pterophoridae & & & \\
\hline 74 & & Pterophorinae & Plume moth & Exelastis atomosa (Walsingham) \\
\hline $\mathbf{X}$ & Lasiocampidae & & & \\
\hline 75 & & Pinarinae & Jamun lappet moth & Metanastria sp. \\
\hline $\mathbf{X I}$ & Eupterotidae & & & \\
\hline 76 & & Eupterotinae & Hairy caterpillar & Eupterote mollifera (Moore) \\
\hline XII & Cossidae & & & \\
\hline 77 & & Metarbelinae & Bark borer & Indarbela tetraonis (Moore) \\
\hline XIII & Psychidae & & & \\
\hline 78 & & Oiketicinae & Bagworm moth & Eumeta sp. \\
\hline
\end{tabular}

identified belonging to the order Lepidoptera as their body, wings and appendages were densely clothed with overlapping scales. Further, they were classified under the suborder Glossata because of the presence of coiled tongue (haustellum) for sucking nectar and absence of mandibulate mouth parts in adults. The suborder Glossata was further identified to clades viz., Obtectomera, Macroheterocera, Apoditrysia and Ditrysia. The moths recorded were further categorized under nine superfamilies and 13 families based on Nieukerken Van et al. (2011) classification. The results of moths recorded from the study area of Annamalai Nagar during December 2015 to November 2016 using various methods are furnished in Table 1. A total of 2,679 moths were recorded using all the three types of methods employed in the study. Among various methods, light trap method could help to collect maximum of 2,253 moths followed by manual collection (369) and host rearing (57). It indicated that a share of $84 \%$ moth observed only through light trapping (Fig. 1). From the results, it is clear that light trap was superior in collection of moths during night times. Similar findings were reported by Chandra and Sambath (2013) who found that light trap is an efficient method to attract nocturnal moths. The same results were also obtained by Gadhikar et al. (2013) who found that moths were effectively collected during night times with the help of light 
Kathirvelu, C. et al. / J. Appl. \& Nat. Sci. 11(2): 404 - 409 (2019)

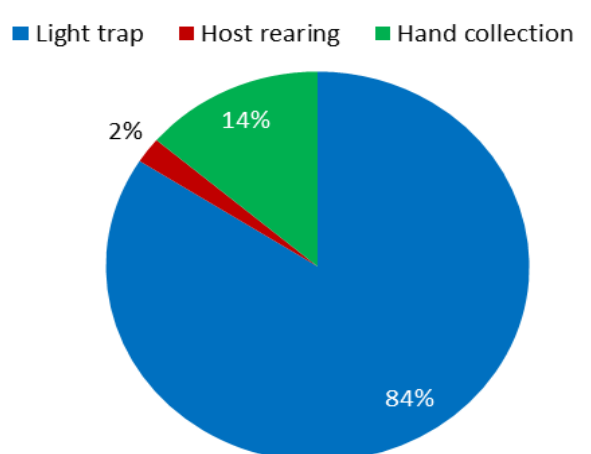

Fig.1. Moths recorded in Annamalai Nagar using various methods during December 2015 to November 2016.

trap erected in the collection area. The results are in tune with the findings of Fry and Waring (1996) that have collected noctuid moths with the help of light traps fitted at different places during night time.

The results of the moths recorded from the study area during December 2015 to November 2016 using light trap were witnessed maximum (656) in Orchard followed by Experimental farm with 629 numbers among the four sites of collection. The other sites like garden land and new area were found to contain suit 541 and 427 numbers respectively during all the four seasons (Table 2). This might be due to continuous presence of vegetable crops and also fruit tree crops in the locality; and also weed plants around the orchard. The results corroborate with the findings of the Pavithradharani (2016) who found that light trapping was suitable for collection of moths in orchards and also in hilly tracts. The other methods like host rearing will be useful only for certain available species in the vicinity whereas the manual collection will yield only limited species only when it is abundant.

The diversity of moths was observed in the study area of Annamalai Nagar during 2015 to 2016 indicated the presence of 70 genera and 56 species identified under nine superfamilies of Clades viz., Obtectomera (Pyraloidea and Thyridoidea) Macroheterocera (Noctuoidea, Bombycoidea, Geometroidea, Lasiocampoidea) Apoditrysia (Pterophoroidea and Cossoidea) Ditrysia (Tineoidea) and 13 families namely Crambidae, Erebidae, Noctuidae, Sphingidae, Bombycidae, Uraniidae, Thyrididae, Eupterotidae, Geometridae, Pterophoridae, Lasiocampidae, Cossidae and Psychidae were observed in the study area (Table 3). Out of which, the family Erebidae alone had 28 genera and 25 species and thus was found to be the superior family followed by Crambidae (13), Sphingidae (07) and Noctuidae (05). This may be due to the least number of cropping and less rain fall in the study area lead to lack of crops in both the ecosystems. Similar results were obtained by Gurule et al. (2013) that Eribidae was the dominant family out of the five families recorded under the super family Noctuoidae. The results are different from that reported by Chandra and Sambath (2013) who found that out of 250 morpho- species of moths collected in the Tawang District of Arunachala Pradesh, in which 102 species and 81 genera were under 12 diversified families. The family Geometridae dominated with $48 \%$ of total species recorded followed by Erebidae (26\%).

\section{Conclusion}

A total of 70 genera and 56 species were identified from the study area, out of which the family Erebidae alone had 28 genera and 25 species and found to be the superior family. Among the methods employed for observation, light trap was found to be the best than other methods. However, an extensive survey with other sampling methods including, crepuscular netting, baiting, larval searching, diurnal nectaring and malaise trapping may yield new record to get a detailed periodic estimate of the faunal diversity of moths in this area.

\section{ACKNOWLEDGEMENTS}

The authors are thankful to the authorities of Annamalai University for their permission to carry out this study at Experimental farm and orchard, Faculty of Agriculture, Annamalai University.

\section{REFERENCES}

1. Beccaloni, G.W., Scoble,M.J., Robinson,G.S., Downton, A.C., and Lucas. S.M. (2003). Lepindex-The Global Lepidoptera Names Index: An online website published by the Natural History Museum, London.

2. Bell, T.R.D. (1919). The common butterflies of the plains of India (including those met within the hill stations of the Bombay Presidency). Journal of the Bombay Natural History Society, 26(2): 438-487.

3. Bell,T.R.D, and Scot, F.B. (1937). Fauna of British India including Ceylon and Burma. Moths. Vol. V. Sphingidae. Taylor and Francis, London, UK.

4. Benton, T.G. (1995). Biodiversity and biogeography of Henderson Island insects. Biological Journal of the Linnean Society, 56 (1-2): 245-259.

5. Bingham CT. (1905). The Fauna of British-India including Ceylon and Burma. Butterflies. Vols. I and II. Taylor and Francis, London, UK.

6. Bingham CT. (1907). The Fauna of British-India including Ceylon and Burma. Butterflies. Vols. I and II. Taylor and Francis, London, UK.

7. Brehm, G. (2005). Diversity and community structure of geometrid moths of disturbed habitat in a montane area in the Ecuadorian Andes. Journal of Research Lepidoptera, 38: 1-14.

8. Chandra, K. and Sambath, S. (2013). Moth diversity of Tawang District, Arunachal Pradesh, India. Journal of Threatened Taxa, 5 (1): 3565-3570.

9. Chandra, K. and. Nema, D.K. (2007). Fauna of Madhya Pradesh (including Chhattisgarh) Part-I, State Fauna Series Zoological Survey of India, 
Kolkata, 15: 347.

10.De Niceville L, and Marshall G.F.L. (1990). The Butterflies of India, Burma andCeylon. Vol. II. Calcutta Central Press, Calcutta, India.

11.Fry, R. and Waring. P. (1996). A guide to moth traps and their use. The Amateur Entomologist, 24: (4) 60.

12.Gadhikar, Y.A., Sambath, S.Y., Yattoo, I. (2013). A preliminary report on the moths (Insecta: Lepidoptera: Heterocera) fauna from Amravati, Maharashtra. International Journal of Science and Research, 4 (7): 883-887.

13.Gurule Sachin A. and Santosh, M. Nikam (2011). Nikam. Inventory of Lepidopterous insects in North Maharashtra and survey for moth diversity. Flora and Fauna, 17: 165 - 174.

14.Gurule Sachin, A. and Santosh M. Nika (2013). The moths (Lepidoptera: Heterocera) of northern Maharashtra: a preliminary checklist. Journal of Threatened Taxa, 5(12): 4693-4713.

15. Hampson, G. F. (1895). On the classification of the Schoenobiinae and Crambinae, two subfamilies of moths of the family Pyralidae. Proceedings of the Zoological Society of London, 897-974p.

16. Hampson, G.F. (1892). The Fauna of British India including Ceylon and Burma, Moths - volume 1. Taylor and Francis, London, 527pp.

17. Hampson, G.F. (1893). The Fauna of British India including Ceylon and Burma, Moths - volume 2. Taylor and Francis, London, 609pp.

18. Hampson, G.F. (1894). The fauna of British India including Ceylon and Burma, Moths - volume 3. Taylor and Francis, London, 546pp.

19. Hampson, G.F. (1896). The fauna of British India including Ceylon and Burma, Moths - volume 4. Taylor and Francis, London, 595pp.

20. Holloway, J. D. (1989). The moths of Borneo (Part 12); Noctuidae: Noctuinae, Heliothinae, Hadeninae, Acronictinae, Amphipyrinae, Agaristinae. Malayan Nature Journal, 43: 57-226.

21.Kristensen, N. P., Scoble, M. J. and Karsholt, O. (2007). Lepidoptera phylogeny and systematics: the state of inventorying moth and butterfly diversity.
Zootaxa, 1668: 699 - 747.

22.Mallet, J. (2007). Taxonomy of Lepidoptera: the scale of the problem. The Lepidoptera Taxome Project. University College, London.

23.Mani, M.S. (1986). Butterflies of the Himalaya. Oxford and IBH, New Delhi, India.

24.Nieukerken Van, E. J. V., Kaila, L., Kitching, I. J., Kristensen, N. P., Lees, D. C., Minet, J., Mitter, C., Mutanen, M., Regier, J. C., Simonsen, T. J., Wahlberg, N., Yen, S. H., Zahiri, R., Adamski, D., Baixeras, J., Bartsch, D., Bengtsson, B. A., Brown, J. W., Bucheli, S. R., Davis, D. R., Prins, J. D., Prins, W. D., Epstein, M. E., Gentili-Poole, P., Gielis, C., Hattenschwiler, P., Hausmann, A., Holloway, J. D., Kallies, A., Karsholt, O. and Kawahara, A. (2011). Order Lepidoptera Linnaeus, 1758. In: Animal Biodiversity: An outline of higher-level classification and survey of taxonomic richness. Zhang, Z.Q. (eds.). Zootaxa, 3148: 212-221.

25.Pavithradharani, S.K. (2016). Preliminary studies on taxonomy of lepidopteran fauna at selected localities of Tamil Nadu, M.Sc., thesis, Department of Entomology, Annamalai University, Annamalai Nagar, Tamil Nadu.

26.Peter Smetacek. (2011). Review of Indian Lepidoptera collections and their significance in conservation. ENVIS Bulletin: Arthropods and their Conservation in India (Insects \& Spiders), 14 (1): 135-139.

27.Shah Kr. S. and Mitra, B. (2015). Moth (Insecta: Lepidoptera) fauna and their Insect Predators Associated with the tea gardens and the surrounding natural ecosystem environs in Northern West Bengal, India. The Journal of Zoology Studies, 2(6): 01-05.

28. Talbot, G. (2013). The Fauna of British India including Ceylon and Burma: Butterflies. Volume 1. Today and Tomorrow's printers and publishers, New Delhi. 600 p.

29.Triplehorn, C. A. and Johnson, N. F. (1989). Borror and Delongs study of Insects. Saunders College Publishers, San Francisco. 807p.

30.Wilson,E.O. (1992). Fluctuations in abundance of tropical insects. American Naturalist, 112: 1017-1045. 